\title{
Proposal for an instrument for the admission of the elderly to long- term care facilities: elaboration and validation
}

\section{Abstract}

Objective: To elaborate and validate an instrument for the admission of the elderly to long-term care facilities. Method: A methodological study was performed, divided into two phases, the first of which was the elaboration of the instrument based on a literature review of research published in journals indexed in SciELO and in databases such as Medline, LILACS, IBECS, Embase and books related to gerontology, defining theoretical dimensionality through relevant information to support individualized and integral care for the elderly. The second phase of the study involved validation by nine experts from a multidisciplinary field. Six criteria were used to validate the construct, for which the experts chose one of the following options: adequate, inadequate or requires greater adequacy and also, when necessary, added suggestions. The decision to maintain, reformulate or exclude items was based on the Percentage of Consensus (PC) among the experts, for which consensus of more than $80 \%$ was adopted as the value of statistical significance. Results: The scientific evidence base for the construction of the instrument consisted of anamnesis and physical examination domains, segmented in ten and four sections, respectively. Half of the sections achieved a score above that proposed, four of which received a maximum consensus score in all criteria. Conclusion: The instrument was developed and proved to be consistent for applicability by different professionals in the area, with the aim of promoting geriatric care focused on the health of the institutionalized patient.

\footnotetext{
Centro Universitário de Maringá (UNICESUMAR), Departamento de Medicina. Maringá, Paraná, Brasil.

2 Centro Universitário de Maringá (UNICESUMAR), Instituto Cesumar de Ciência, Tecnologia e Inovação (ICETI), Programa de Pós-Graduação em Promoção da Saúde. Maringá, Paraná, Brasil.
}

\author{
Eloá Sanches Martins Corrêa' $\mathbb{1}$ \\ Maria Paula Pizzaia Arrabaçal $\mathbb{E}$ \\ Mirian Ueda Yamaguchi2 ${ }^{2}$ \\ Marcelo Picinin Bernuci ${ }^{2}$ ID
}

Keywords: Data Collection. Geriatric Nursing. Validation Studies. Aged. Homes for the Aged. Health of Institutionalized Elderly. 


\section{INTRODUCTION}

There has been a notable increase in the world's elderly population in recent decades. It is therefore important to understand that the aging process brings morphological, functional, biochemical and psychological changes that generate greater vulnerability, a higher incidence of pathological processes and difficulties in performing daily activities ${ }^{1}$.

In Brazil, approximately half of the elderly population need some help to perform at least one of their daily activities and a significant minority are highly dependent ${ }^{2}$. This data, coupled with the rapid demographic transition brings serious challenges and consequences for health services for the geriatric population, public policies and the family environment ${ }^{3}$.

As a result, the Brazilian Society of Geriatrics and Gerontology (or SBGG) and specialized committees have been debating the nature of Long-term Care Facilities for the Elderly (LTCFs), which can be governmental or non-governmental institutions, of a residential nature, dedicated to people aged 60 and over, with or without family support, in full conditions of dignity, freedom and citizenship ${ }^{4}$.

From 2007 to 2009, Brazil had 3,549 LTCFs, responsible for accommodating around $0.6 \%$ to $1.3 \%$ of the total elderly population, yet there are no well-defined selection criteria for the occupying of places ${ }^{2,5}$. Thus, in the context in which we live, which is marked by great socioeconomic and cultural inequalities, geriatric clinics are extremely heterogeneous in relation to care, structure, financial support and the population served ${ }^{3}$.

Although the minimum standards of operation of these institutions is established by Resolution RDC No. 283/2005, following the guidelines of the National Policy of the Elderly ${ }^{6}$, many operate in precarious conditions, without systematization of care and with little individualized care ${ }^{3}$. In addition, institutionalization itself has a decisive impact on the health-disease process of the elderly, and should be composed of actions that address all the needs of these people, preserving their autonomy and reducing their limitations?
Therefore, the elaboration of an instrument to be applied in the admission of patient-residents to the LTCFs, which collects information to support the planning of comprehensive and humanized gerontological-geriatric care, is necessary.

Following the elaboration of the instrument, the validation of to what extent it measures the desired phenomenon of interest is essential. The validation techniques are content validity, criteria validity and construct validity, and the content validity used in the present study attests to whether each element of the instrument contemplates the proposed theoretical dimension, ensuring its quality and veracity ${ }^{8}$.

The opinion of a committee of experts in the gerontological-geriatric area on the items of the instrument, known as the Delphi technique, was employed along with content analysis?.

Based on the above, the present study aimed to develop and validate an instrument for the admission of the elderly to long-term care facilities, to be used by qualified professionals from all areas of health, thus representing an interdisciplinary instrument that meets the current and future needs of the elderly population.

\section{METHOD}

A methodological study was conducted between September 2017 and November 2018, and divided into two stages: 1) elaboration of the instrument for the multidisciplinary team for the admission of elderly persons to the LTCF; 2) validation and reformulation of the instrument.

For data collection, a bibliographic survey was conducted in journals indexed in the Scientific Electronic Library Online (SciELO) and in the PubMed databases, available through the Virtual Health Library (VHL), Medline, LILACS, IBECS and Embase using descriptors such as: data collection; validation studies; geriatric nursing; elderly person; long-term care facility for the elderly and health of the institutionalized elderly person.

From the integrative review of scientific articles, books related to gerontology and random consultations with professors from the area of health qualified in the 
process of construction and validation of instruments, the theoretical definitions, identification of domains and formation of sections and topics constitutive of the instrument were elucidated.

The theoretical dimensionality of the instrument was based on Anamnesis and Physical Examination, two major domains shared in the daily applicability of a range of health professionals, but with different denominations depending on area, such as in Nursing, in which anamnesis is designated as nursing history, but which ultimately share the same concept: fundamental data collection tools to support the formulation of diagnostic hypotheses and therapeutic planning ${ }^{10,11}$.

Thus, the Anamnesis and Physical Examination domains were divided, respectively, into ten and four sections, in order to organize and facilitate the completion and visualization of information.

Subsequently, the content validation method was performed, which consisted of verifying the quality of the instrument through the subjective judgment of a committee of experts. This step made it possible to ensure the validity of the instrument, that is, to indicate precisely what it was intended to measure. The evaluation of the experts involved qualitative and quantitative methodology. The measurement of the quality of the instrument was related to the clarity, pertinence, relevance and representativeness of the items, and the qualitative evaluation comprised the analysis of the domains in terms of the division of the set of items. The quantitative evaluation was measured by the degree of consensus among the experts ${ }^{12,13}$.

In the absence of a defined standard for the selection of experts and in line with the objective of the study ${ }^{9,14}$, the eligibility criteria were: to be a health professional with clinical experience in LTCFs or in the care of the institutionalized elderly for at least five years; to be a researcher in the gerontological-geriatric area and understand the methodological process employed in the construction of the instrument.

From this, a data survey was performed of health professionals from the city of Maringá, Paraná, Brazil, who worked in the geriatric sector, through the recommendation of the Post-Graduate Department in Health Promotion of the Medical
Course of the Centro Universitario de Maringá (Unicesumar). Then, through curriculum analysis via the Lattes Platform, researchers were selected that fit the study outline.

It was decided to select an odd number of professionals, between five and ten, to make up the committee, due to the fact that there is no consensus in the literature as to the exact number of members required. Thus, nine experts were invited to compose a multidisciplinary committee, via e-mail, in order to add distinct theoretical and practical knowledge, extolling the validation process: two geriatricians, one nurse, two physiotherapists, a speech therapist, a nutritionist, a pharmacist and a professional with a degree in Nursing and Pharmacy.

After the experts agreed to contribute to the research, the data collection instrument and an explanatory document about the purpose of the study and its evaluation method were sent via e-mail ${ }^{12}$. At the same time, a guiding script containing a tableorganized instrument was sent to evaluate domains, sections and items.

The criteria used by experts to evaluate the instrument in relation to the adequacy of the data contained in each dimension were: 1) format and presentation; 2) readability and ease of completion; 3) clarity and comprehension; 4) pertinence of content; 5) relevance of items and 6) proper sequence. Parameters one, two, and six refer to the aspect, appearance, and exteriority of the form; item three assesses whether the wording is intelligible, transparent, with coherent and unambiguous expressions; pertinence analyzes whether the data reflect the concepts involved and achieve the proposed objectives; and, finally, relevance verifies the significance of each item ${ }^{12,13,15}$.

The experts evaluated each section and item against the six criteria, for which they selected only one of the options: Adequate, Inadequate, or Requires Greater Adequacy. At the end of the script they recorded their opinions, criticisms and suggestions in the open spaces.

The forms were collected in the first half of February 2018, after 30 days. For data analysis, the answers were manually tabulated and all comments 
were organized in tables. The decision to maintain, reformulate or delete items was based on the Percentage of Consensus (PC) among the experts, with a value of statistical significance of consensus above $80 \%$ adopted $^{13-15}$.

It should be noted that the participation of the experts did not consider them subjects of the research, but as evaluators of a proposal for a data collection instrument, therefore, the approval of the Research Ethics Committee involving human beings or a Form of Free and Informed Consent is not required.

\section{RESULTS}

After an extensive literature review of the scientific literature, the theoretical frameworks were established and the representative domains of the clinical evaluation of the institutionalized elderly persons chosen. Universal dimensions were used for the multiprofessional data collection, since the instrument is not restricted to a certain professional class.
The instrument consisted of two domains: Anamnesis and Physical Examination, common tools used by healthcare professionals to collect patient information. The researchers then returned to literature to define which dimensions would be relevant for the clinical evaluation of the institutionalized elderly, which constituted the sections of the instrument.

The Anamnesis domain was fragmented into the following sections: identification; legal guardian; reason for institutionalization; history of previous diseases; neurological evaluation; auditory and visual evaluation; gastrointestinal and nutritional evaluation; genitourinary evaluation; evaluation of lifestyle and basic activities of daily living. The Physical Examination consisted of: vital signs, anthropometric data, general evaluation and evaluation of skin and mucous membranes.

After the elaboration of the instrument, validation was performed by the nine experts with experience in caring for the institutionalized elderly. The profile of the experts is presented in Table 1.

Table 1. Data of professionals who evaluated the instrument designed for admission to LTCFs. Maringá, Paraná, 2018.

\begin{tabular}{|c|c|c|}
\hline Variables & $\mathrm{n}(\%)$ & Mean (standard-deviation) \\
\hline Age (years) & & $39.33( \pm 10.03)$ \\
\hline $34-39$ & $3(33.33)$ & \\
\hline $40-49$ & $4(44.44)$ & \\
\hline $50-57$ & $2(22.22)$ & \\
\hline \multicolumn{3}{|l|}{ Gender } \\
\hline Female & $7(77.77)$ & \\
\hline Male & $2(22.22)$ & \\
\hline Time since graduation (years) & & $16.22( \pm 10.60)$ \\
\hline $10-19$ & $6(66.66)$ & \\
\hline $20-29$ & $2(22.22)$ & \\
\hline $30-39$ & $1(11.11)$ & \\
\hline \multicolumn{3}{|l|}{ Academic qualification } \\
\hline Specialization & $7(77.77)$ & \\
\hline Master's & $5(55.55)$ & \\
\hline Time working (years) & & $15.66( \pm 10.98)$ \\
\hline $6-10$ & $2(22.22)$ & \\
\hline $11-20$ & $5(55.55)$ & \\
\hline $21-30$ & $2(22.22)$ & \\
\hline \multicolumn{3}{|l|}{ Institution } \\
\hline Long Term Care Facility for the Elderly & $5(55.55)$ & \\
\hline
\end{tabular}


To identify the experts, an alphabetical letter system was used, represented by: A and B-doctors; C-pharmacist; D and E- physiotherapists; F - speech therapist; $\mathrm{G}$ - pharmacist and nurse; $\mathrm{H}$ - nurse and I- nutritionist.

The results of the evaluation of the body of experts of the consensus and representativeness of the items in each section are shown in Table 2.
According to the responses of the experts regarding the consensus and representativeness of the sections, eight achieved consensus rates above $80 \%$ in all the stipulated criteria. Of these, five remained unchanged, as shown in Chart 1, while in the remaining suggestions to modify some terms to better cover the proposed content were accepted, as shown in Chart 2.

Table 2. Distribution of level of consensus among experts regarding the six evaluation criteria in the content validation process. Maringá, Paraná, 2018.

\begin{tabular}{|c|c|c|c|c|c|c|}
\hline $\begin{array}{l}\text { Indicators } \\
\text { Analysis Criteria }\end{array}$ & $\begin{array}{l}\text { Format and } \\
\text { Presentation }\end{array}$ & $\begin{array}{l}\text { Readability } \\
\text { and Ease of } \\
\text { Completion }\end{array}$ & $\begin{array}{l}\text { Clarity \& } \\
\text { Comprehension }\end{array}$ & $\begin{array}{l}\text { Pertinence } \\
\text { of Content }\end{array}$ & $\begin{array}{l}\text { Relevance } \\
\text { of Items }\end{array}$ & $\begin{array}{l}\text { Proper } \\
\text { order }\end{array}$ \\
\hline \multicolumn{7}{|l|}{ Anamnesis } \\
\hline Identification & $100 \%$ & $100 \%$ & $100 \%$ & $100 \%$ & $100 \%$ & $100 \%$ \\
\hline Legal Guardian & $100 \%$ & $100 \%$ & $100 \%$ & $100 \%$ & $100 \%$ & $100 \%$ \\
\hline Reason for institutionalization & $100 \%$ & $100 \%$ & $100 \%$ & $100 \%$ & $100 \%$ & $100 \%$ \\
\hline History of previous illness & $78 \%$ & $78 \%$ & $89 \%$ & $89 \%$ & $100 \%$ & $78 \%$ \\
\hline Neurological evaluation & $89 \%$ & $89 \%$ & $67 \%$ & $78 \%$ & $100 \%$ & $67 \%$ \\
\hline Auditory and visual evaluation & $89 \%$ & $89 \%$ & $89 \%$ & $89 \%$ & $89 \%$ & $89 \%$ \\
\hline $\begin{array}{l}\text { Gastrointestinal and nutritional } \\
\text { evaluation }\end{array}$ & $78 \%$ & $78 \%$ & $67 \%$ & $89 \%$ & $89 \%$ & $67 \%$ \\
\hline Genitourinary evaluation & $78 \%$ & $89 \%$ & $78 \%$ & $89 \%$ & $89 \%$ & $78 \%$ \\
\hline Living habits & $89 \%$ & $100 \%$ & $89 \%$ & $89 \%$ & $89 \%$ & $89 \%$ \\
\hline $\begin{array}{l}\text { Evaluation of basic activities } \\
\text { of daily living }\end{array}$ & $78 \%$ & $89 \%$ & $89 \%$ & $78 \%$ & $100 \%$ & $89 \%$ \\
\hline \multicolumn{7}{|l|}{ Physical Exam } \\
\hline Vital signs & $100 \%$ & $100 \%$ & $100 \%$ & $100 \%$ & $100 \%$ & $100 \%$ \\
\hline Anthropometric data & $100 \%$ & $100 \%$ & $100 \%$ & $89 \%$ & $100 \%$ & $89 \%$ \\
\hline Overall evaluation & $89 \%$ & $89 \%$ & $89 \%$ & $89 \%$ & $100 \%$ & $89 \%$ \\
\hline Skin and mucous membrane & $89 \%$ & $89 \%$ & $89 \%$ & $89 \%$ & $100 \%$ & $78 \%$ \\
\hline
\end{tabular}


Chart 1. Unchanged sections due to scores higher than stipulated in the six established criteria. Maringá, Paraná, 2018.

Identification

Name: Sex: ( ) F ( ) M

Date of birth: CPF: ID:

Origin: ( ) home ( ) general hospital ( ) psychiatric hospital ( ) home for the elderly ( ) other:

Profession: ( ) retired ( ) Schooling:

Health plan: ( ) no ( ) yes Which? $\mathrm{N}^{\circ}$ SUS:

Religion: ( ) Catholic ( ) Spiritist ( ) Evangelical ( ) Atheist ( ) other

Date of admission:

Legal Guardian

Name:

Degree of kinship: RG:

Telephone: residential $\mathrm{CPF}:$ cell commercial

Home address:

Number: Flat No.:

Neighborhood: CEP: ity/State:

Other contacts:

Name: Telephone:

Name Telephone: Degree of kinship:

Name: Telephone: Degree of kinship:

Reason for institutionalization

( ) Seeking specialized and elderly-focused care

( ) Family conflict and tensions

( ) Has no family or close relatives

( ) Court order

( ) Patient's own choice

Vital Signs

Blood pressure: $\mathrm{mmHg} \mathrm{O}_{2}$ saturation: $\% \quad \mathrm{~T}:$ ${ }^{\circ} \mathrm{C}$

Pulse:_________ bpm Characteristics: ( ) Regular ( ) Irregular ( ) Full ( ) Filiform

RR: rpm Breathing: ( ) Spontaneous

( ) Oxygen therapy - > ( ) Nasal Catheter ( ) Tracheostomy ( ) Oxygen Mask

Overall Evaluation

Overall state: ( ) Good ( ) Fair ( ) Poor

Level of consciousness: ( ) Conscious ( ) Unconscious ( ) Partial Loss - Confused

Pallor: ( ) Coloration ( ) Hyper-coloration ( ) Paleness _-_ / ++++

Hydration: ( ) Hydrated ( ) Dehydrated _-_ / ++++

Jaundice: ( ) Anicteric ( ) Icteric __ / ++++

Cyanosis: ( ) Acyanotic ( ) Cyanotic _- / ++++ 
Chart 2. Alterations made following specific suggestions of experts. Maringá, Paraná, 2018.

\begin{tabular}{|ll|}
\hline Sections & Suggestions of experts accepted \\
\hline $\begin{array}{l}\text { Auditory and } \\
\text { visual evaluation }\end{array}$ & $\begin{array}{l}\text { Inserted: item "In what year would you estimate your last ophthalmological appointment took } \\
\text { place?". }\end{array}$ \\
\hline Living habits & $\begin{array}{l}\text { Excluded: subitem "Little sleep". } \\
\text { Reformulations: item "Occupational activity" substituted by "Leisure activity". } \\
\text { Subitem "Disturbed sleep" substituted by "Interrupted sleep" and "Insomnia" by "Initial insomnia". } \\
\text { Inserted: item "Physical activity" and subitem "Excessive sleep". }\end{array}$ \\
\hline $\begin{array}{l}\text { Anthropometric } \\
\text { data }\end{array}$ & $\begin{array}{l}\text { Inserted: items "Weight", "Height", "Body Mass Index", "Calf circumference", the calculation } \\
\text { of Body Mass Index by weight and height and the classification of reference values specific for } \\
\text { the elderly }\end{array}$ \\
\hline
\end{tabular}

The experts selected the option Requires greater adequacy for all the criteria that had a score of less than 0.8 , while the option Inadequate was chosen once, by Expert D, for the criteria of adequate sequence in Gastrointestinal and nutritional evaluation.

The mean AP value for each of the six parameters was $0.90 ; 0>92 ; 0.89 ; 0.91 ; 0.97$ and 0.87 , respectively. All achieved means over 0.80 , with the criteria of relevance having the best score $(97 \%)$ and proper sequence the lowest $(87 \%)$.

There were 48 suggestions in all, with each expert suggesting between one and 14 reformulations, some of which, despite the percentage indicating valid content, were accepted, in order to improve the instrument. Additionally, all the sections that did not achieve the determined percentage were reformulated and adapted.
The sections History of Disease, Gastrointestinal and nutritional evaluation, Genitourinary evaluation and Skin and mucous membrane evaluation underwent major adaptations, with the disparity between the initial version and the definitive version becoming clear, as can be seen in Chart 3 .

In contrast, the sections Neurological evaluation and Evaluation of Basic activities of daily living underwent few changes. In the first, two experts proposed the following: substitution of the item "communication" with "comprehension"; the word "speech" was added to the item "communication" (speech/communication)"; the word "stutter" was excluded and the sequence of the items was inverted. In the second section, three experts $(\mathrm{A}, \mathrm{B}$ and $\mathrm{H})$ opted to include the Katz Scale, since the initial instrument included all the items that composed the scale in the form of questions and did not generate a score for dependence.

Chart 3. Initial and final versions of sections: History of previous disease, Gastrointestinal and nutritional evaluation, Genitourinary evaluation and Skin and mucous membrane evaluation. Maringá, Paraná, 2018.

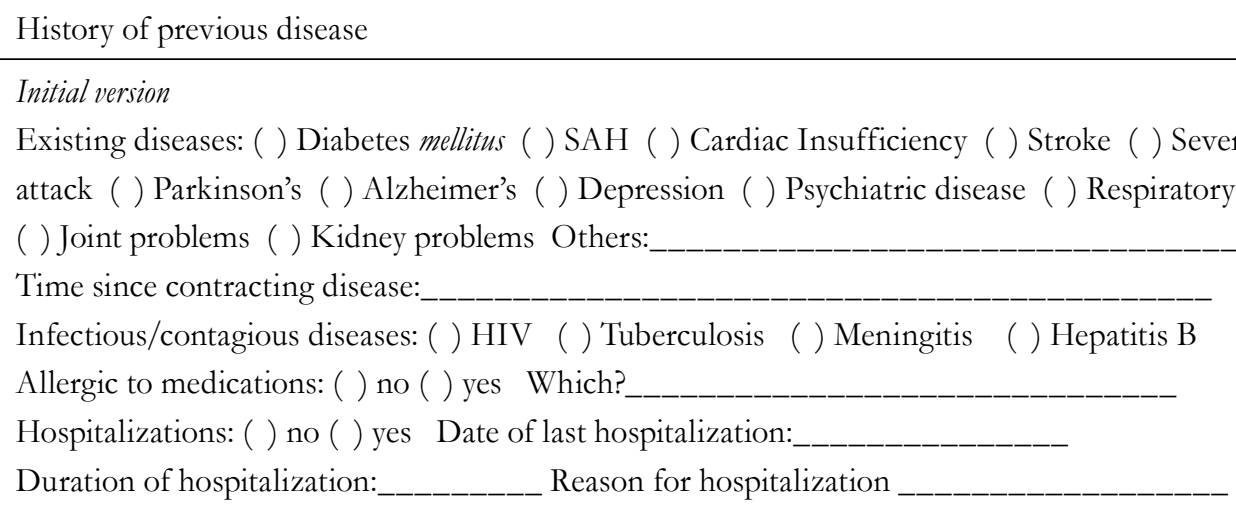


Continuation of Chart 3

Have you suffered a fall? ( ) no ( ) yes

Have you suffered a fracture? ( ) no ( ) yes

How long ago?

Region affected:

Have you undergone surgery in the past: ( ) no ( ) yes

Which?

Vaccination status

Mark vaccinations taken with an $\mathrm{X}$ :

( ) Flu: annual ( ) Pneumo 13 ( ) Pneumo 23 ( ) Diphtheria, Tetanus and pertussis: every ten years

( ) Hepatitis B: 3 doses (0, 1, 6 months) ( ) Herpes-zoster: single dose over the age of 60

Do you take medication? ( ) no ( ) yes

Medications being used:

\begin{tabular}{|l|l|l|}
\hline Name & Indication & Posology \\
\hline & & \\
\hline & & \\
\hline & & \\
\hline & & \\
\hline & & \\
\hline
\end{tabular}

\section{Final Version}

Existing diseases: ( ) Diabetes mellitus ( ) SAH ( ) Cardiac Insufficiency ( ) Stroke ( ) Acute myocardial infarction ( ) Neoplasm ( ) Joint problems ( ) Osteoporosis ( ) Renal problems ( ) Parkinson's ( ) Dementia ( ) Alzheimer's ( ) Vascular disease ( ) Levy Bodies

( ) Psychiatric disease: ( ) Respiratory disease:

Others:

Infectious diseases: ( ) HIV ( ) Pneumonia ( ) Urinary infection

( ) Influenza A H1N1 ( ) Scabies ( ) Others:

Allergic to medication: ( ) no ( ) yes Which?

Hospitalizations: () no () yes Date of last hospitalization:

Duration of hospitalization:

Reason for hospitalization

Have you suffered a fall? ( ) no ( ) yes

Have you suffered a fracture? ( ) no ( ) yes Location:

How long ago did you have the fracture?

Have you previously undergone surgery? ( ) no () yes

Which?

Vaccination status

Mark vaccinations taken with an $\mathrm{X}$ :

( ) Annual flu ( ) Pneumo 13 ( ) Pneumo 23

( ) Diphtheria, tetanus and pertussis - every ten years

( ) Hepatitis B - 3 doses (0, 1, 6 months)

( ) Herpes-zoster - single dose over the age of 60 
Continuation of Chart 3

Do you take medication? ( ) no ( ) yes

Medications being used:

\begin{tabular}{|l|l|l|}
\hline Name & Indication & Posology \\
\hline & & \\
\hline & & \\
\hline & & \\
\hline & & \\
\hline & & \\
\hline
\end{tabular}

Gastrointestinal and Nutritional evaluation and Genitourinary evaluation

Initial Version

Gastrointestinal and nutritional evaluation

Feeding route: ( ) Oral ( ) NGT ( ) NET ( ) Parenteral ( ) Jejunostomy

( ) Gastrostomy Quantity:

Oral disorders: ( ) Use of dental implants ( ) Difficulty swallowing ( ) Difficulty chewing

Type of food: ( ) Solid ( ) Paste ( ) Semiliquid ( ) Liquid

Use of assistive techniques (straw, thickener, etc.): ( ) no ( ) yes

Eating frequency: ______- meals/day.

Have you lost weight in the last 3 months? ( ) no ( ) yes How much? _____________kg

Food allergies: ( ) no ( ) yes Which?

Food preference?

Dietary restrictions (do not like to or cannot eat)?

Intestinal voiding routes: ( ) Normal ( ) Diaper ( ) Ostomy - Type/location:

If use diapers, do you have contact dermatitis (rash)? ( ) no ( ) yes

Notes:

\section{Genitourinary evaluation}

Urinary voiding routes: ( ) Spontaneous ( ) Indwelling Urinary Catheter ( ) Intermittent Urinary Catheter
( ) Diaper ( ) Collector
( ) Dialysis ______-_times/week

Do you have urinary incontinence? ( ) no ( ) yes

Notes:

Final Version

Digestive and Urinary Evaluation

Urinary voiding routes: ( ) Spontaneous ( ) Catheter ( ) Diaper ( ) Collector

( ) Dialysis times/week

Intestinal voiding routes: ( ) Normal ( ) Diaper ( ) Ostomy - Type/location:

Do you have urinary incontinence? ( ) no ( ) yes Do you have fecal incontinence? ( ) no ( ) yes

If use diapers, do you have contact dermatitis (rash)? ( ) no ( ) yes

Notes:

\section{Nutritional Evaluation}

Feeding route: ( ) Oral ( ) NGT ( ) NET ( ) Parenteral ( ) Gastrostomy ( ) Jejunostomy

Type of diet: ( ) Solid ( ) Paste ( ) Semiliquid ( ) Liquid

Oral disorders: ( ) Use of dental implants ( ) Difficulty swallowing ( ) Difficulty chewing 
Continuation of Chart 3

Have you lost weight in the last 3 months? ( ) no ( ) yes How much? $\mathrm{kg}$

Use of assistive techniques (straw, thickener, etc.): ( ) no () yes

Eating frequency: meals/day.

Food allergies: ( ) no ( ) yes Which?

Food preference:

Dietary restrictions (do not like to or cannot eat):

Notes:

Skin and mucous membranes evaluation

Initial version

Place an $\mathrm{X}$ in the type of skin disorder and corresponding location (if any):

\begin{tabular}{|c|c|c|c|c|c|c|c|c|}
\hline \multirow[t]{2}{*}{ Location } & \multicolumn{8}{|c|}{ Skin disorder } \\
\hline & Hematoma & Petechiae & Wound & Chafing & Blister & Cut & Nodule & Scar \\
\hline \multicolumn{9}{|l|}{ Head and neck } \\
\hline \multicolumn{9}{|l|}{ Back } \\
\hline \multicolumn{9}{|l|}{ Chest } \\
\hline \multicolumn{9}{|l|}{ Abdomen } \\
\hline \multicolumn{9}{|l|}{ Upper right limb } \\
\hline \multicolumn{9}{|l|}{ Upper left limb } \\
\hline \multicolumn{9}{|l|}{ Lower right limb } \\
\hline Lower left limb & & & & & & & & \\
\hline
\end{tabular}

Other skin disorder? ( ) no ( ) yes Which?

Do you have pressure ulcers? ( ) no ( ) yes Diameter:
Where?

cm Depth: $\mathrm{cm}$

Location:

\begin{tabular}{|l|l|l|}
\hline \multirow{2}{*}{ Location } & \multicolumn{2}{|l|}{$\begin{array}{l}\text { Place an X in the location and } \\
\text { corresponding side, if any }\end{array}$} \\
\cline { 2 - 3 } & Left & Right \\
\hline Sacrum & & \\
\hline Trochanter & & \\
\hline Sciatic tuberosity & & \\
\hline Malleolus & & \\
\hline Calcaneus & & \\
\hline Hallux & & \\
\hline Other (Which): & & \\
\hline
\end{tabular}

\section{Degree}

( ) I - Healthy skin with redness.

( ) II - Acute epidermis and dermis, may have blisters.

( ) III - Impairment of subcutaneous tissue, without bone, muscle or tendon exposure.

( ) IV - Total tissue loss with bone, muscle or tendon exposure.

Treatment / dressing: ( ) no ( ) yes Which?

Edema: ( ) no ( ) Upper limbs ( ) Lower limbs ( ) Sacrum ( ) Ascites

( ) Generalized Intensity:_-_/++++ 
Continuation of Chart 3

\section{Final Version}

Do you have any skin disorders? ( ) no ( ) yes Which? ( ) Petechiae ( ) Hematoma ( ) Vesicle/Blister ( ) Nodules

( ) Cracking ( ) Chafing ( ) Pustules ( ) Scars

( ) Other: Where?

Do you have pressure ulcers? ( ) no ( ) yes Location:

Description of wound:

Treatment/dressing: ( ) no ( ) yes Which?

Description of wound:

Treatment/dressing: ( ) no ( ) yes Which?

\begin{tabular}{|c|c|c|c|c|c|}
\hline \multicolumn{5}{|c|}{ Evaluation of risk of pressure ulcers } & \multirow[b]{3}{*}{ Value } \\
\hline \multirow{2}{*}{ Risk factors } & \multicolumn{4}{|l|}{ Score } & \\
\hline & 1 & 2 & 3 & 4 & \\
\hline $\begin{array}{l}\text { Sensory } \\
\text { perception }\end{array}$ & Totally limited & Very limited & Slightly limited & No limitation & \\
\hline Moisture level & Constantly moist & Often moist & $\begin{array}{l}\text { Occasionally } \\
\text { moist }\end{array}$ & Rarely moist & \\
\hline Activity & Bedfast & Chairfast & $\begin{array}{l}\text { Walks } \\
\text { occasionally }\end{array}$ & Walks frequently & \\
\hline Mobility & $\begin{array}{l}\text { Completely } \\
\text { immobile }\end{array}$ & Very limited & Slightly limited & No limitations & \\
\hline Nutrition & Very poor & $\begin{array}{l}\text { Probably } \\
\text { inadequate }\end{array}$ & Adequate & Excellent & \\
\hline Friction/Shear & Problem & Potential problem & $\begin{array}{l}\text { No apparent } \\
\text { problem }\end{array}$ & - & \\
\hline
\end{tabular}

Edema: ( ) no ( ) yes Location: Intensity: /++++

\begin{tabular}{|l|}
\hline Score \\
\hline$\leq 9-$ Extremely heightened risk \\
$10-12-$ Heightened risk \\
$13-14-$ Moderate risk \\
$15-18-$ Low risk \\
$>19-$ No risk \\
\hline
\end{tabular}

\section{DISCUSSION}

The importance of developing a specific data collection instrument for the admission of the elderly to long-term care facilities became evident when we identified the absence of such an instrument. The research on this theme also evidenced the inadequacies of publications available in the literature that contemplate integrative care among the various professional classes, aiming at holistic and integral care for the geriatric patient.

Therefore, for the development of the present study, it was difficult to obtain articles related 
specifically to data collection and the unification of information that could be shared and used by all professionals of the multidisciplinary team.

The choice of theoretical framework presupposed the union of information based on clinical medical examination and nursing history contained in the systematization of nursing care (SNC). Both processes are based on obtaining patient data through anamnesis and physical examination to better trace diagnoses and possible therapeutic approaches, thus ensuring individualized and continuous care ${ }^{18,19}$.

Thus, the references supported the structuring of the instrument, for which it was chosen to build two domains: Anamnesis and Physical Examination, which, in turn, were constituted by their respective sections and these by their respective items.

The first section refers to Identification, which provides the sociodemographic profile of the patient. These data are extremely important because they provide support for the analysis of anatomicalphysiological differences between genders and the alternation of disease prevalence in relation to age and $\operatorname{sex}^{11}$.

The second section comprises the data of the Legal Guardian, i.e. identifies the person responsible for the hospitalization of the elderly person and other necessary contacts.

The third section discusses the Reason for Institutionalization, the reason that motivated seeking the health service, which indirectly indicates the social environment in which the elderly person was inserted and the expectation regarding the desired care.

It is noteworthy that the first, second and third sections achieved a 100\% consensus level for all evaluation criteria, and no recommendations were made for alterations.

The next section deals with History of Previous Diseases, in which three evaluated criteria that achieved a AP of 0.78 were reviewed and reformulated. The insertion of the dementia syndrome, suggested by three experts, is justified because it encompasses several irreversible diseases that compromise the higher brain functions and impair the functionality of the individual. Among these, Alzheimer's disease, vascular dementia and Lewy bodies were introduced as sub-items, as the former is responsible for $60 \%$ of all dementias, followed in order by the others $\left(\right.$ Chart 3) ${ }^{20-22}$.

In the same section, the terms meningitis and hepatitis B were replaced by urinary tract infection and pneumonia. About $15 \%$ to $30 \%$ of all infections found in elderly residents of LTCFs are due to urinary tract infection ${ }^{23}$. In developed countries, more than $50 \%$ of hospitalizations for pneumonia are in the elderly, with a higher prevalence of respiratory infection in institutionalized elderly persons than those who live in the community ${ }^{24}$.

Chronic diseases such as heart disease, diabetes mellitus and strokes negatively influence the functional capacity of the elderly and this deterioration progressively increases due to the number of morbidities ${ }^{25}$.

The fifth section of the instrument refers to the Neurological Evaluation, which analyzes the production and comprehension of the spoken language, neurological changes and motor skills. It was difficult to choose the items for this section as it is a very broad area and, at the same time, specific to certain health professionals. Thus, the inserted items subsidize a neurological evaluation based on overall understanding so that all of the multidisciplinary team know how to complete it.

The sixth section deals with the Auditory and Visual Evaluation that asks about the existence of hearing alterations, visual acuity and the use of corrective methods, since the decrease of sensory capacity is related to an increase in falls, cognitive and functional decline, depressive processes, social isolation and immobility ${ }^{2,6}$. Given a rate of consensus of over 0.8 in all items of the section, there were no significant changes, only the addition proposed by Expert B (Chart 2).

In the initial instrument, the seventh section comprised the Gastrointestinal and Nutritional Evaluation and the eighth the Genitourinary Evaluation. The analysis of the experts identified that the two sections 
were interconnected and for this reason received scores below the stipulated level in four evaluation criteria, and were reformulated in a different manner from the initial version, as shown in Chart 3.

After making the proposed changes, in the final version, the Digestive and Urinary Evaluation included urinary and fecal elimination, urinary incontinence and fecal incontinence, with the latter recommended by three experts (A, B and $\mathrm{H})$. Both urinary and fecal incontinences are highly prevalent in institutionalized elderly persons, generating serious psychosocial consequences, such as social isolation, changes in self-esteem and self-image, and contribute to lower Katz Scale scores ${ }^{25,27,28}$.

The Nutritional Evaluation section included questions about the diet of the elderly, data relevant to the maintenance of an adequate nutritional state in a context of so many obstacles, such as the existence of chronic diseases; polypharmacy; aging-related physiological changes that interfere with appetite, nutrient intake and absorption, and social and economic issues ${ }^{29}$.

According to Silva and Dias ${ }^{29}$, institutionalized women have a higher risk of malnutrition than men, while men are more malnourished than women. This study also confirmed the relationship between the influence of nutritional status on the functionality of the elderly, with men, who are statistically more malnourished, having a lower functional capacity and becoming more dependent on the activities of daily living. On the other hand, Barbosa et al. ${ }^{25}$ found that women are more dependent in instrumental activities of daily living and, although they live longer, do so in worse living conditions.

Regarding the Living Habits section, which consisted of four items that investigate the consumption of tobacco, alcohol, fitness for certain leisure activities, including physical activity, and sleep patterns; it is important to specify which type of physical activity the elderly practice, as this age group prioritizes aerobic activities, flexibility, balance, endurance and muscle strength ${ }^{29}$.

The evaluation of sleep quality is extremely important, since insomnia and drowsiness are frequent complaints of the elderly, increasing the risk of falls, as well as having cognitive, respiratory and cardiovascular repercussions ${ }^{30}$.

The section Evaluation of the Basic Activities of Daily Living aims to assess the degree of dependence of the patient in performing activities of self-care ${ }^{31}$.

The Katz Scale assesses six basic self-care activities: bathing; dressing oneself; performing hygiene; transferring from bed to chair and vice versa; being continent and having the ability to feed oneself. The final score provides the degree of dependence of the individual. Its construction is based on the conclusion that functional loss follows an equal pattern of decline, that is, the ability to bathe is lost first, followed by an inability to dress, transfer and feed oneself, and when there is recovery, it occurs in the reverse order ${ }^{25}$.

Regarding the Physical Examination domain, the sections include: Vital Signs, Anthropometric Data, General Evaluation and Skin and Mucosal Membrane Evaluation, which were restructured after the evaluation of the experts.

Thus, the first section refers to the indicators of the body's vital functions, which is important due to the fact that these data are fundamental for observing health and adequate physiology in the respiratory, cardiac, endocrine and neural areas ${ }^{32}$.

The second section, Anthropometric Data, despite being formed by a group of elements which are difficult to collect among the elderly population, are widely used because they are non-invasive, low cost and allow the nutritional status of the patient to be assessed ${ }^{29}$. The item calf circumference measurement was added as it is sensitive data for the evaluation of muscle mass; assisting in the detection of risks, in order to ensure adequate interventions to improve the quality of life of the elderly, as well as the body mass index and its reference values adopted for the elderly in Brazil ${ }^{16,17}$.

The Overall Evaluation section was created for subjective evaluation, using patient data and being interpreted by professionals according to their experiences. In this context, checking the overall 
state allows an understanding of how the disease has affected the body as a whole. The evaluation of the level of consciousness, although a little more complex, allows the individual's ability to remain alert to be tested through responsiveness to environmental and verbal stimuli ${ }^{16}$. At the same time, the state of hydration can be assessed through abrupt weight loss, skin changes in moisture, elasticity and turgor, mucous membrane changes in relation to moisture and eye changes. In addition, skin color changes were also included in the initial version as: pallor (attenuation or disappearance of rosy skin color), jaundice (yellowish skin and mucous membranes resulting from bilirubin accumulation) and cyanosis (bluish skin color and mucous membranes due to reduced serum hemoglobin) ${ }^{33}$.

Finally, the last section, Skin and Mucous Membranes Evaluation, focused on elemental lesions - solid formations, liquid collections, changes in thickness and loss, and tissue repair - was initially organized in the form of tables to be completed. In this section, one expert (A) suggested excluding the items "skin disorders" and "pressure ulcer evaluation" from the table. In contrast, two experts (A and $\mathrm{H}$ ) requested the incorporation of the Braden Scale into the instrument (Chart 3).

The Braden Scale assesses the risk for pressure ulcer, consisting of six topics: sensory perception (ability to react to pressure related to discomfort); moisture; activity; mobility (ability to change and control body position); nutrition; friction and shear. The sum of the score of these parameters can vary from 6 to 23, where the lowest values indicate worse conditions ${ }^{34}$. The scale is important as it complements the multidisciplinary clinical evaluation, with the purpose of identifying at risk individuals and supporting strategies for pressure ulcer prevention.

In short, after its construction and series of evaluations by the nine experts, the instrument was considered adequate in terms of meeting the needs of the health professionals for the admission of the elderly to LTCFs and their care while they remain institutionalized.
The process experienced in the elaboration of this instrument allowed the authors of this study to understand the relevance of multidisciplinary work, since, even after an extensive search for information in scientific databases, the numerous suggestions from professionals with their expertise was a relevant and fundamental factor for the functionality of the instrument.

\section{CONCLUSION}

Research in scientific and operational databases provided the necessary theoretical basis for the construction of the present instrument. However, it was difficult to choose the content inserted in the initial version, as the questions were required to cover universal dimensions for use by the multiprofessional team.

Subsequently, the instrument was evaluated by experts in the gerontological-geriatric area, a process designated as validation. Content validity, according to the opinion of the experts, demonstrated the satisfactory relevance, pertinence and representativeness of the inserted items. Some recommended suggestions allowed the inclusion, reformulation and exclusion of items to improve the clarity and comprehension of the instrument.

Thus, the present study achieved its objective - to develop and validate an instrument for the admission of the elderly in long-term care facilities that can be used by all healthcare professionals and, consequently, to support better care planning for this specific population.

This is an innovative instrument that is notable for its originality, since the justification for creating it was the absence of another multiprofessional form that allows a holistic view of institutionalized elderly persons and integrated care. Thus, the next step would be the application of the final instrument in long-term care facilities for the elderly, aimed at verifying its practicality, functionality and validity in clinical practice. 


\section{REFERENCES}

1. Silva NA, Pedraza DF, Menezes TN. Desempenho funcional e sua associação com variáveis antropométricas e de composição corporal em idosos. Ciênc. saúde coletiva [Internet]. 2015 [acesso em 10 de out. 2017]; 20(12): 3723-3732. Disponível em: http://www.scielo.br/scielo.php?script=sci arttext\&pid=S1413-81232015001203723\&lng=en. http://dx.doi.org/10.1590/1413-812320152012.01822015.

2. De Freitas MC, Guedes MVC, De Galiza FT, Nogueira JM, Onofre MR. Idosos residentes em uma instituição de longa permanência: adaptação à luz de Callista Roy. Rev. bras. enferm. [Internet]. 2014 [acesso em 24 de set. 2017] ; 67(6): 905-912. Disponível em: http://www. scielo.br/scielo.php?script $=$ sci_arttext\&pid $=$ S003471672014000600905\&lng=en. http://dx.doi. org/10.1590/0034-7167.2014670607.

3. Camargos MC. Instituições de longa permanência para idosos: um estudo sobre a necessidade de vagas. Rev. bras. estud. Popul. [Internet]. 2014 [Acesso em 4 Set. 2017]; 31(1): 211-217. Disponível em: http://www. scielo.br/scielo.php?script=sci_arttext\&pid=S010230982014000100012\&lng=pt\&nrm=iso

4. Roquete FF, Batista CCRF, Arantes RC. Demandas assistenciais e gerenciais das instituições de longa permanência para idosos: uma revisão integrativa (2004-2014). Rev. bras. geriatr. gerontol. [Internet]. 2017 [acesso em 13 Set. 2017]; 20(2): 286-299. Disponível em: http://www.scielo.br/scielo.php?script=sci_ arttext\&pid=S1809-98232017000200286\&lng=en. http://dx.doi.org/10.1590/1981-22562017020.160053.

5. De Oliveira PB, Tavares DMS. Condições de saúde de idosos residentes em Instituição de Longa Permanência segundo necessidades humanas básicas. Rev. bras. enferm. [Internet]. 2014 [acesso em 15 Set. 2017]; 67( 2 ): 241-246. Disponível em: http://www. scielo.br/scielo.php?script $=$ sci_arttext\&pid=S003471672014000200241\&lng=en. http://dx.doi. org/10.5935/0034-7167.20140032.

6. De Carvalho VL. Perfil das instituições de longa permanência para idosos situadas em uma capital do Nordeste. Cad. saúde colet. [Internet]. 2014 [acesso em 12 Set. 2017]; 22(2): 184-191. Disponível em: http://www.scielo.br/scielo.php?script $=$ sci arttext\&pid=S1414-462X2014000200184\&lng=en. http://dx.doi.org/10.1590/1414-462X201400020012.

7. Duarte LMN. O PROCESSO DE INSTITUCIONALIZAÇÃO DO IDOSO E AS TERRITORIALIDADES: ESPAÇO COMO LUGAR?.Estud. interdiscipl. Envelhec. [Internet]. 2014 [Acesso em 20 Set. 2017]; 19(1): 201-217. Disponível em: https://seer.ufrgs.br/RevEnvelhecer/ article/view/33754/31010.
8. Cunha CM, Neto OPA, Stackfleth R. Principais métodos de avaliação psicométrica da validade de instrumentos de medida. Rev. Aten. Saúde [Internet]. 2016 [Acesso em 16 Set. 2017]; 14(47): 75-83. Disponível em: http://seer.uscs.edu.br/index.php/ revista_ciencias_saude/article/view/3391/pdf

9. Bellucci JJAB, Matsuda LM. Construção e validação de instrumento para avaliação do Acolhimento com Classificação de Risco. Rev. bras. enferm. [Internet]. 2012 [acesso em 21 Nov. 2017]; 65( 5 ): 751-757. Disponível em: http://www.scielo. br/scielo.php?script $=$ sci_arttext\&pid=S003471672012000500006\&lng=en. http://dx.doi. org/10.1590/S0034-71672012000500006.

10. Santos DMA, Sousa FGM, Paiva MVS, Santos AT. Construção e implantação do Histórico de Enfermagem em Terapia Intensiva Pediátrica. Acta paul. enferm. [Internet]. 2016 [acesso em 11 de Set. 2017]; 29( 2 ): 136-145. Disponível em: http://www. scielo.br/scielo.php?script $=$ sci_arttext\&pid $=$ S010321002016000200136\&lng=en. http://dx.doi. org/10.1590/1982-0194201600020.

11. Sousa AMK, Garcia BM, Silva CCL, Ferreira JL, Vieira LCP, Vieira LRP et al. IMPORTÂNCIA DA ANAMNESE PARA FISIOTERAPIA: REVISÃO BIBLIOGRÁFICA. Rev. Educ. Saúde [Internet]. 2016. [Acesso em 20 Set. 2017]; 4(1):114-119. Disponível em: http://periodicos.unievangelica.edu. br/index.php/educacaoemsaude/article/view/1709

12. Alexandre NMC, Coluci MZO. Validade de conteúdo nos processos de construção e adaptação de instrumentos de medidas. Ciênc. saúde coletiva [Internet]. 2011 [acesso em 13 Set. 2017]; 16( 7 ): 3061-3068. Disponível em: http://www.scielo. br/scielo.php?script=sci_arttext\&pid=S141381232011000800006\&lng=en. http://dx.doi. org/10.1590/S1413-81232011000800006.

13. Cunha CM, Neto OPA, Stackfleth, R. Principais métodos de avaliação psicométrica da validade de instrumentos de medida. Rev. Aten. Saúde [Internet]. 2016 [acesso em 17 Set. 2017]; 14(47): 75-83. Disponível em: http://seer.uscs.edu.br/index.php/ revista_ciencias_saude/article/view/3391.

14. Guimarães PV, Haddad MCL, Martins EAP. Validação de instrumento para avaliação de pacientes graves em ventilação mecânica, segundo o ABCDE. Rev. Eletr. Enf. [Internet]. 2015 jan/mar [acesso em 22 Nov. 2017];17(1): 43-50. Disponível em: http:// dx.doi.org/10.5216/ree.v17i1.23178. - doi: 10.5216/ree. v17i1.23178. 
15. Marinho PML, Campos MPA, Rodrigues EOL, Gois CFL, Barreto IDC. Construção e validação de instrumento de Avaliação do Uso de Tecnologias Leves em Unidades de Terapia Intensiva. Rev. LatinoAm. Enfermagem [Internet]. 2016 [acesso em 24 Set. 2017]; 24: e2816. Disponível em: http://www. scielo.br/scielo.php?script $=$ sci_arttext\&pid=S010411692016000100442\&lng=en. Epub Dec 19, 2016. http://dx.doi.org/10.1590/1518-8345.1002.2816.

16. Pereira IFS, Spyrides MHC, Andrade LMB. Estado nutricional de idosos no Brasil: uma abordagem multinível. Cad. Saúde Pública [Internet]. 2016 [acesso em 21 Mar. 2018]; 32( 5 ): e00178814. Disponível em: http://www.scielo. br/scielo.php?script $=$ sci_arttext\&pid $=$ S0102311X2016000500709\&lng=en. Epub June 03, 2016. http://dx.doi.org/10.1590/0102-311X00178814.

17. Puggina ACG, Silva MJP. Pacientes com desordem de consciência: respostas vitais, faciais e musculares frente música ou mensagem. Rev. Bras. Enferm. [Internet]. 2015 [acesso em 13 Mai. 2018] ; 68( 1 ): 102-110. Disponível em: http://www.scielo. br/scielo.php?script $=$ sci_arttext\&pid=S003471672015000100102\&lng=en. http://dx.doi. org/10.1590/0034-7167.2015680114p.

18. Riegel F, Junior NJO. Processo de enfermagem: implicações para a segurança do paciente em centro cirúrgico. Cogitare Enferm. [Internet]. 2017 [acesso em 11 Nov. 2017]; 22(4):01-05. Disponível em: https://revistas.ufpr.br/cogitare/article/view/45577 . http://dx.doi.org/10.5380/ce.v22i1.45577

19. Coelho AV, Molina RM, Labegalini MPC, Ichisato SMT, Pupulim JSL. Validação de um histórico de enfermagem para unidade de terapia intensiva pediátrica. Rev. Gaúcha Enferm. [Internet]. 2017 [acesso em 5 Nov. 2017]; 38( 3 ): e68133. Disponível em: http://www.scielo. br/scielo.php?script $=$ sci_arttext\&pid=S198314472017000300409\&lng=en. Epub Apr 05, 2018. http://dx.doi.org/10.1590/1983-1447.2017.03.68133.

20. Santos JI, Rodrigues CJ, Zogheib JB, Malachias MVB, Rezende BA. Avaliação de parâmetros hemodinâmicos e vasculares na doença de Alzheimer, demência vascular e alterações cognitivas leves: um estudo piloto. Rev. bras. geriatr. gerontol. [Internet]. 2017 [acesso em 16 Mar. 2018]; 20( 5 ): 670-678. Disponível em: http://www.scielo. br/scielo.php?script=sci_arttext\&pid=S180998232017000500670\&lng=en. http://dx.doi. org/10.1590/1981-22562017020.160211.
21. Sancho LG. Atenção à saúde na síndrome demencial: qual será o impacto econômico dessa atenção no Brasil?. Saúde debate [Internet]. 2015 [Acesso em: 22 Abr. 2018]; 39( 105 ): 551-560. Disponivel em: http://www.scielo.br/scielo.php?script $=$ sci_ arttext\&pid=S0103-11042015000200551\&lng=en. http://dx.doi.org/10.1590/0103-110420151050002021.

22. Parmera JB, Nitrini R. Demências: da investigação ao diagnóstico. Demências: da investigação ao diagnóstico. Rev. Med. [Internet]. 2015 [Acesso em: 10 dez 2017]; 94(3): 179-84. Disponível em: http:// www.revistas.usp.br/revistadc/article/view/108748

23. Melo LS, Ercole FF, Oliveira DU, Pinto TS, Victoriano MA, Alcoforado CLGC. Urinary tract infection: a cohort of older people with urinary incontinence. Rev. Bras. Enferm. [Internet]. 2017 [acesso em 24 Jun. 2018] ; 70( 4 ): 838844. Disponível em: http://www.scielo.br/ scielo.php?script $=$ sci_arttext\&pid $=$ S003471672017000400838\&lng=en. http://dx.doi. org/10.1590/0034-7167-2017-0141.

24. Souza SC, Mello RGB, Morsch P, Prates CS, Pereira GN. Diagnósticos de enfermagem em idosos institucionalizados e associação com o processo de incapacidade funcional. Rev. Bras. Ciências do Envelhec. 2014 [acesso em 22 Mar. 2018];11(3): $257-$ 266. Disponível em: http://seer.upf.br/index.php/ rbceh/article/view/4061

25. Barbosa BR, De Almeida JM, Barbosa MR, Barbosa LARR. Avaliação da capacidade funcional dos idosos e fatores associados à incapacidade. Ciênc. saúde coletiva [Internet]. 2014 [acesso em 18 Jul. 2018] ; 19 ( 8 ): 3317-3325. Disponível em: http://www. scielo.br/scielo.php?script $=$ sci_arttext\&pid=S141381232014000803317\&lng=en. http://dx.doi. org/10.1590/1413-81232014198.06322013.

26. Magrini AM, Santos TMM. Verificar a influência do uso do aparelho auditivo no rastreio cognitivo de idosos. Rev. Distúrb. Comum. [Internet]. 2017 [Acesso em: 24 Nov. 2017]; 29(01): 122-132. Disponivel em: https://revistas.pucsp.br/index.php/ dic/article/view/29034

27. Silva MA, Aguiar ESS, Matos SDO, Lima JO, Costa MML, Soares MJGO. Prevalência de incontinência urinária e fecal em idosos: Estudo em Instituições de longa permanência para idosos. Estud. interdiscipl. envelhec. [Internet]. 2016 [acesso em: 05 Jul. 2018]; 21(1): 249-261. Disponivel em: https://seer.ufrgs.br/ RevEnvelhecer/article/view/46484. 
28. Ferretti-Rebustini R, Balbinott M, Jacob-Filho W, Rebustini F, Suemoto C, Pasqualucci C et al. Validity of the Katz Index to assess activities of daily living by informants in neuropathological studies. Rev. escol. enferm. USP [Internet]. 2015 [Acesso em 28 Mar. 2018]; 46(6): 944-950. Disponível em: https://www. ncbi.nlm.nih.gov/pubmed/27419678.

29. Silva JM, Dias SFL. Analysis of functional capacity and nutritional status of nursing home residentes. ReonFacema.[Internet].2017 [acesso em 11 jul.2019]; 3(4):719-726. Disponível em: http://www.facema.edu. br/ojs/index.php/ReOnFacema/article/view/274/165

30. Monteiro NT, Ceolim MF. Qualidade do sono de idosos no domicílio e na hospitalização. Texto Contexto Enferm. [Internet]. 2014 [Acesso em 23 Ago. 2018]; 23(2): 356-364. Disponivel em: http://www.scielo.br/ pdf/tce/v23n2/pt_0104-0707-tce-23-02-00356.pdf.

31. Pinto AH, Lange C, Pastore CA, Llano PMP, Castro DP, Santos F. Functional capacity to perform activities of daily living among older persons living in rural areas registered in the Family Health Strategy. Ciênc. saúde coletiva [Internet]. 2016 Nov [acesso em 17 Jun. 2018] ; 21(11): 3545-3555. Disponível em: http://www.scielo. br/scielo.php?script=sci_arttext\&pid=S141381232016001103545\&lng=en. http://dx.doi. org/10.1590/1413-812320152111.22182015.
32. Teixeira CC, Boaventura RP, Souza ACS, Paranaguá TTB, Bezerra ALQ, Bachion MM, et al. VITAL SIGNS MEASUREMENT: AN INDICATOR OF SAFE CARE DELIVERED TO ELDERLY PATIENTS. Texto contexto - enferm. [Internet]. 2015 [acesso em 25 Abr. 2018]; 24( 4 ): 10711078. Disponível em: http://www.scielo.br/ scielo.php?script $=$ sci_arttext\&pid $=$ S010407072015000401071\&lng=en. http://dx.doi. org/10.1590/0104-0707201500003970014.

33. Fortes TML, Suffredini IB. Avaliação de pele em idoso: revisão da literatura. J Health Sci Inst. [Internet]. 2014 [acesso em 12 Dez. 2017]; 32(1):94101. Disponível em: https:/www.unip.br/presencial/ comunicacao/publicacoes/ics/edicoes/2014/01_janmar/V32_n1_2014_p94a101.pdf

34. Moro JV, Caliri MHL. Úlcera por pressão após a alta hospitalar e o cuidado em domicílio. Esc. Anna Nery. 2016 [acesso em 15 Dez. 2017]; 20(3): e20160058. Disponível em: http://www.scielo.br/pdf/ean/ v20n3/1414-8145-ean-20-03-20160058.pdf 